\title{
The Effect of Economic Policy Uncertainty in the US on the Stock Market Performance in Canada and Mexico
}

\author{
Vichet Sum \\ Correspondence: Vichet Sum, School of Business and Technology, University of Maryland - Eastern Shore, \\ Princess Anne, MD, 21853, USA. Tel: 1-410-651-6531. E-mail: vsum@umes.edu
}

\author{
Received: July 23, $2012 \quad$ Accepted: August 17, $2012 \quad$ Online Published: October 15, 2012 \\ doi:10.5539/ijef.v4n11p165 URL: http://dx.doi.org/10.5539/ijef.v4n11p165
}

\begin{abstract}
This paper investigates the effect of economic policy uncertainty in the United States on stock market performance in Canada and Mexico. Using monthly returns of the Canada S\&P/TSX-300 Total Return Index from 1985:2 to 2012:5 and Mexico SE Total Return Index from 1988:1 to 2012:5, this study shows that the increased changes in economic policy uncertainty in the US negatively affect stock market performance in Canada and Mexico. Although the changes in the U.S. trade balance do not influence the effect of the changes in economic policy uncertainty in the US on the stock market performance in Canada and Mexico, the returns on the S\&P 500 do have an impact on this effect. The findings suggest that stock market performance in Canada and Mexico is linked to the economic policy conditions and stock performance in the US. The implication of this finding is that market participants in Canada and Mexico do pay attention to the economic policy conditions and stock performance in the US.
\end{abstract}

Keywords: economic policy uncertainty, stock market performance, USA, Canada, Mexico

JEL Classifications: E60, G12, G14

\section{Introduction}

In attempts to better understand price and return behaviors of financial assets, macroeconomists have tried to empirically investigate the ability of various macro variables (Cochrane 1991b; Cooper \& Priestley 2005; Lamont, 2000; Lettau \& Ludvigson, 2001a; Menzly, Santos \& Veronesi, 2004; Piazzesi Schneider \& Tuzel, 2005) in predicting stock returns to complement the predictability of portfolio-based models. For instance, the predictability of uncertainty in the real economy and various economic policies on financial markets has been empirically studied. Sum (2012a) uses a vector autoregression analysis to analyze U.S. data and show that stock market excess returns negatively respond to the increased changes in economic policy uncertainty. Another study by Sum (2012b) shows that the changes in economic policy uncertainty in Europe negatively affect all stock market returns in the Eurozone, Croatia, Norway, Russia, Switzerland, Turkey and Ukraine, and the effect is statistically significant for all countries except Croatia and seven members (Bulgaria, Estonia, Latvia, Lithuania, Malta, Slovakia and Slovenia) of the European Union. Paster and Veronesi (2012) propose that government policy uncertainty is negatively associated with stock prices. Bansal and Yaron (2004) find that the falling of asset prices is a response to economic uncertainty. Bansal, Khatchatrian and Yaron (2005) find a negative linkage between asset prices and the increase in economic uncertainty. Ozoguz (2009) shows that stock prices are negatively related to higher uncertainty among investors. Dzielinski (2011) provide evidence about the drop of stock returns in the week following a high degree of economic uncertainty.

In recent decades, the world economy has become globally connected more than ever; a disruptive shockwave to an economy can travel to neighboring countries and across the globe instantly. The developments in one country can indirectly and directly affect the economies of neighboring countries and other countries around the world. The effect can be significantly strong when the transmission is originated from one of the world's leading economies; this phenomenon has been well documented in the international economic and financial transmission and spillovers literature. For instance, Forbes and Chinn (2004) report that regional spillovers are determined by trades; the authors also show that the spillovers in a given region are triggered by the largest economy, and the developments in the United States affect all regions. Becker, Finnerty and Friedman (1995) show that US news and information partially explain the spillovers between the US and UK equity markets. In addition, Ehrmann and Fratzscher (2009) analyze 50 stock markets around the world and find that stock market returns negatively 
respond to a tightening monetary policy in the United States. Studies conducted by these researchers (Awad \& Goodwin, 1998; Chinn \& Frankel, 2004; Ehrmann, Fratzscher, \& Rigobon, 2011) show significant cross-border spillovers in bond yields among advanced economies including the US. Kim (2001) also shows that monetary policy shocks in the United States have a significant effect on foreign long-term yields and output.

Financial economists have studied the linkage between the international financial markets. For instance, King and Wadhwani (1990) argue that because rational agents observe and rationalize information from price innovations in other financial markets, there exists a correlation between financial markets. A study conducted by Lin, Engle and Ito (1994) shows that returns on the US stock market is interrelated with returns on the Japanese markets. Wongswan (2006) shows that stock markets in Korea and Thailand are affected by macroeconomic announcements in the United States and Japan. Hausmann and Wongswan (2011) show that international equity prices are significantly affected by surprises in Federal Reserve FOMC announcements during 1994-2005; a similar finding is documented in a study conducted by Ehrmann and Fratzscher (2006) and also reported by Ammer, Vega, and Wongswan (2008). Ehrmann, Fratzscher, and Rigobon (2005) find that financial shocks in the Eurozone have a greater effect on bond yields in the US than the reverse. Because the size of the economy and the well-established financial markets in the United States, shocks to economic activities and other macroeconomic variables in the US are likely to affect foreign markets; this claim is supported by various empirical studies (Bayoumi \& Swiston, 2007; Ehrmann \& Fratzscher, 2005; Goldberg \& Leonard, 2003). Therefore, it is the intent of this study to investigate the effect of economic policy uncertainty in the United States on stock market performance of its neighboring countries namely Canada and Mexico.

This study is necessary because it contributes to the further understanding how financial markets of the neighboring countries respond to the shocks of economic policy uncertainty in the US. The results of this study add important information to the global financial transmission and spillovers literature. The findings from this study offer market participants useful information related to investment and risk management in the capital markets.

\section{Method and Data}

Monthly data on economic policy uncertainty in United States spanning from 1985:1 -2012:5 are obtained from the Economic Policy Uncertainty Index website located at http://www.policyuncertainty.com; this index is constructed by Baker, Bloom, and Davis (2012). Readers are strongly encouraged to read the detailed methodology of how the index is constructed by accessing at the methodology section at the Economic Policy Uncertainty Index website located at http://www.policyuncertainty.com/methodology.html. The data of historical monthly index values of the S\&P 500 Total Return Index, Canada S\&P/TSX-300 Total Return Index from 1985:1 to 2012:5 and Mexico SE Total Return Index from 1988:1 to 2012:5 are collected from the Global Financial Data database. The monthly data of the U.S trade balance with Canada and Mexico are obtained from the U.S. Census Bureau located at http://www.census.gov/foreign-trade/balance.

For the analysis purpose, the historical monthly returns (period percentage change) on the stock market indices are calculated; the first difference is calculated for the economic policy uncertainty index to take care of the non-stationary issue in the series. The time-varying OLS regression analyses (Equation 1 to 3) are computed for the effect of the changes in economic policy uncertainty in the United States on the stock market performance in the United States, Canada and Mexico, respectively. In order to see if changes in the U.S. trade balance with Canada and Mexico, respectively, influence the effect of changes in economic policy uncertainty in United States on the stock market performance in Canada and Mexico, the time-varying OLS regressions (Equation 4 and 5) are analyzed. Moreover, in order to see if the returns on S\&P 500 index influence the effect of the changes in economic policy uncertainty in the United States on the performance of stock markets in Canada and Mexico, respectively, the time-varying OLS regression analyses (equation 6 and 7) are carried out. Finally, to examine if changes in the U.S. trade balance with Canada and Mexico, respectively, and returns on the S\&P 500 index influence the effect of changes in economic policy uncertainty in United States on the stock market performance in Canada and Mexico, the last two equations (equation 8 and 9) are computed.

$$
\begin{gathered}
R_{s \& p 500 t}=\alpha+\beta \Delta E P U_{t}+\varepsilon_{t} \\
R_{\text {cant }}=\alpha+\beta \Delta E P U_{t}+\varepsilon_{t} \\
R_{\text {mext }}=\alpha+\beta \Delta E P U_{t}+\varepsilon_{t} \\
R_{\text {cant }}=\alpha+\beta \Delta E P U_{t}+\theta \Delta T_{R D C A N_{t}}+\varepsilon_{t} \\
R_{\text {mext }}=\alpha+\beta \Delta E P U_{t}+\theta \Delta \operatorname{TRDMEX}_{t}+\varepsilon_{t} \\
R_{\text {cant }}=\alpha+\beta \Delta E P U_{t}+\gamma R_{s \& P 500 t}+\varepsilon_{t}
\end{gathered}
$$




$$
\begin{gathered}
R_{\text {mext }}=\alpha+\beta \Delta E P U_{t}+\gamma R_{s \& P 500 t}+\varepsilon_{t} \\
R_{\text {cant }}=\alpha+\beta \Delta E P U_{t}+\theta \Delta T R D C A N_{t}+\gamma R_{s \& P 500 t}+\varepsilon_{t} \\
R_{\text {mext }}=\alpha+\beta \Delta E P U_{t}+\theta \Delta T R D M E X_{t}+\gamma R_{s \& P 500 t}+\varepsilon_{t}
\end{gathered}
$$

Where:

$R_{S \& P 500 t}=$ return on the S\&P 500 total return index in month $t$

$R_{\text {cant }}=$ return on the Canada S\&P/TSX-300 total return index in month $t$

$R_{\text {mext }}=$ return on the Mexico SE total return index in month $t$

$\triangle E P U_{t}=$ change in the index of economic policy uncertainty in the United States by taking the first difference;

that is the value of economic policy uncertainty index in month $t$ less month $t-1$

$\triangle T R D C A N_{t}=$ change in the U.S. trade balance (export - import) with Canada by taking the first difference; that is the value (in millions) of trade balance in month $t$ less month $t-1$

$\triangle T R D M E X_{t}=$ change in the U.S. trade balance (export - import) with Mexico by taking the first difference; that is the value (in millions) of trade balance in month $t$ less month $t-1$

\section{Results}

Descriptive statistics are reported in Table 1. The correlations among the variables are reported in Table 2. The time-varying regression results reported in Table 3,4 and 5 show a statistically significant negative coefficient for the United States $(\beta=-0.076, t=-5.14)$, Canada $(\beta=-0.079, t=-5.56)$ and Mexico $(\beta=-0.078, t=-2.81)$. When changes in the U.S trade balance with Canada and Mexico, respectively, are included in the regression analyses reported in Table 6 and 7, the regression results still show a statistically significant negative coefficient for Canada $(\beta=-0.079, t=-5.55)$ and Mexico $(\beta=-0.078, t=-2.81)$. The changes in the U.S. trade balance with Canada and Mexico, respectively, have no significant effect on the stock market performance in these two countries. When returns on the S\&P 500 index included in the regression analyses as shown in Table 8 and 9 , the regression coefficient becomes less negative but still significant at the $5 \%$ level for Canada $(\beta=-0.023, t=$ $-2.44)$; the regression coefficient for Mexico $(\beta=-0.015, t=-0.61)$ becomes less negative and statistically insignificant at the 5\% level. The returns on S\&P 500 index fully mediate the effect of the changes in economic policy uncertainty in the United States on the stock market performance in Mexico. When changes in the U.S trade balance with Canada and Mexico, respectively, and returns on the S\&P 500 index included in the regression analyses reported in Table 10 and 11, the regression coefficient is still negative and significant at the $5 \%$ level for Canada $(\beta=-0.023, t=-2.42)$. The regression coefficient for Mexico $(\beta=-0.015, t=-0.61)$ becomes less negative and still statistically insignificant at the $5 \%$ level.

Table 1. Descriptive Statistics

\begin{tabular}{|c|c|c|c|c|c|c|}
\hline$R_{\text {can }}$ & $R_{\text {can }}$ & $R_{\text {mex }}$ & $R_{S \& P 500}$ & $\triangle E P U$ & $\triangle T R D C A N$ & $\triangle T R D M E X$ \\
\hline$R_{\text {mex }}$ & 1.0000 & & & & & \\
\hline$R_{S \& P 500}$ & 0.5158 & 1.0000 & & & & \\
\hline$\triangle E P U$ & 0.7798 & 0.5323 & 1.0000 & & & \\
\hline$\triangle T R D C A N$ & -0.2943 & -0.1624 & -0.2738 & 1.0000 & & \\
\hline \multirow[t]{2}{*}{$\triangle T R D M E X$} & 0.0054 & 0.0017 & -0.0297 & -0.0090 & 1.0000 & \\
\hline & -0.0173 & -0.0021 & 0.0073 & -0.0372 & -0.1339 & 1.0000 \\
\hline
\end{tabular}

\begin{tabular}{lccc}
\hline \multicolumn{1}{c}{ Variables } & Mean & $\begin{array}{c}\text { Standard } \\
\text { Deviation }\end{array}$ & $\#$ of Obs \\
\hline Return on Canada S\&P/TSX-300 Total Return Index & 0.766068 & 4.396819 & 328 \\
Return on Mexico SE Total Return Index & 2.477562 & 8.013095 & 293 \\
Return on S\&P 500 Total Return Index & 0.911767 & 4.523394 & 328 \\
Change in U.S. Economic Policy Uncertainty & 0.266671 & 16.3189 & 328 \\
Change in U.S. Trade Balance with Canada & -1.34116 & 655.2900 & 328 \\
Change in U.S. Trade Balance with Mexico & -18.84299 & 467.6124 & 328 \\
\hline
\end{tabular}

Table 2. Correlations 
Table 3. Time-Varying OLS Regression Results: $R_{s \& p 500 t}=\alpha+\beta \Delta E P U_{t}+\varepsilon_{t}$

\begin{tabular}{lcccc}
\hline & Coefficient & Std. Err. & $\boldsymbol{t}$ & Sig. \\
\hline Constant & 0.93200 & 0.24062 & 3.87 & 0.001 \\
$\beta$ & -0.07590 & 0.01476 & -5.14 & 0.000 \\
R-Square & 0.0750 & & & \\
Adj. R-Square & 0.0721 & & & 0.000 \\
$\mathrm{~F}(1,326)$ & 26.42 & & &
\end{tabular}

Number of Observation $=328$

Table 4. Time-Varying OLS Regression Results: $R_{\text {cant }}=\alpha+\beta \Delta E P U_{t}+\varepsilon_{t}$

\begin{tabular}{lcccc}
\hline & Coefficient & Std. Err. & $\boldsymbol{t}$ & Sig. \\
\hline Constant & 0.78721 & 0.01426 & 3.39 & 0.001 \\
$\beta$ & -0.07929 & 0.23240 & -5.56 & 0.000 \\
R-Square & 0.0866 & & & \\
Adj. R-Square & 0.0838 & & & 0.000 \\
$\mathrm{~F}(1,326)$ & 30.91 & & & \\
\hline
\end{tabular}

Number of Observation $=328$

Table 5. Time-Varying OLS Regression Results: $R_{\text {mext }}=\alpha+\beta \Delta E P U_{t}+\varepsilon_{t}$

\begin{tabular}{lcccc}
\hline & Coefficient & Std. Err. & $\boldsymbol{t}$ & Sig. \\
\hline Constant & 2.49019 & 0.46273 & 5.38 & 0.000 \\
$\beta$ & -0.07883 & 0.02808 & -2.81 & 0.005 \\
R-Square & 0.0264 & & & \\
Adj. R-Square & 0.0230 & & & 0.000 \\
$\mathrm{~F}(1,291)$ & 7.88 & & & \\
\hline
\end{tabular}

Number of Observation $=293$

Table 6. Time-Varying OLS Regression Results: $R_{\text {cant }}=\alpha+\beta \Delta E P U_{t}+\theta \Delta \operatorname{TRDCAN}_{t}+\varepsilon_{t}$

\begin{tabular}{lcccc}
\hline & Coefficient & Std. Err. & $\boldsymbol{t}$ & Sig. \\
\hline Constant & 0.78723 & 0.01426 & 3.38 & 0.001 \\
$\beta$ & -0.07928 & 0.23240 & -5.55 & 0.000 \\
$\theta$ & 0.00001 & 0.00035 & 0.05 & 0.958 \\
R-Square & 0.0866 & & & \\
Adj. R-Square & 0.0810 & & & 0.000 \\
$\mathrm{~F}(2,325)$ & 15.41 & & & \\
\hline
\end{tabular}

Number of Observation $=328$

Table 7. Time-Varying OLS Regression Results: $R_{\text {mext }}=\alpha+\beta \Delta E P U_{t}+\theta \Delta T R D M E X_{t}+\varepsilon_{t}$

\begin{tabular}{lcccc}
\hline & Coefficient & Std. Err. & $\boldsymbol{t}$ & Sig. \\
\hline Constant & 2.48773 & 0.01426 & 5.36 & 0.000 \\
$\beta$ & -0.07894 & 0.23240 & -2.81 & 0.005 \\
$\theta$ & -0.00012 & 0.00096 & -0.13 & 0.958 \\
R-Square & 0.0264 & & & \\
Adj. R-Square & 0.0197 & & & 0.000 \\
$\mathrm{~F}(2,290)$ & 3.94 & & & \\
\hline
\end{tabular}

Number of Observation $=293$ 
Table 8. Time-Varying OLS Regression Results: $R_{\text {cant }}=\alpha+\beta \Delta E P U_{t}+\gamma R_{s \& P 500 t}+\varepsilon_{t}$

\begin{tabular}{lcccc}
\hline & Coefficient & Std. Err. & $\boldsymbol{t}$ & Sig. \\
\hline Constant & 0.10240 & 0.15452 & 0.66 & 0.508 \\
$\beta$ & -0.02352 & 0.00963 & -2.44 & 0.015 \\
$\gamma$ & 0.73476 & 0.03477 & 21.13 & 0.000 \\
R-Square & 0.6152 & & & \\
Adj. R-Square & 0.6128 & & & 0.000 \\
F(2, 325) & 259.77 & & & \\
\hline
\end{tabular}

Number of Observation $=328$

Table 9. Time-Varying OLS Regression Results: $R_{\text {mext }}=\alpha+\beta \Delta E P U_{t}+\gamma R_{s \& P 500 t}+\varepsilon_{t}$

\begin{tabular}{|c|c|c|c|c|}
\hline & Coefficient & Std. Err. & $t$ & Sig. \\
\hline Constant & 0.10240 & 0.40586 & 4.06 & 0.000 \\
\hline$\beta$ & -0.01516 & 0.02490 & -0.61 & 0.543 \\
\hline$\gamma$ & 0.97513 & 0.09538 & 10.22 & 0.000 \\
\hline R-Square & 0.2843 & & & \\
\hline Adj. R-Square & 0.2794 & & & \\
\hline$F(2,290)$ & 57.60 & & & 0.000 \\
\hline
\end{tabular}

Number of Observation $=293$

Table 10. Time-Varying OLS Regression Results: $R_{\text {cant }}=\alpha+\beta \Delta E P U_{t}+\theta \Delta T R D C A N_{t}+\gamma R_{s \& P 500 t}+\varepsilon_{t}$

\begin{tabular}{lcccc}
\hline & Coefficient & Std. Err. & $\boldsymbol{t}$ & Sig. \\
\hline Constant & 0.10240 & 0.15461 & 0.66 & 0.511 \\
$\beta$ & -0.02330 & 0.00964 & -2.42 & 0.016 \\
$\theta$ & 0.00018 & 0.00023 & 0.79 & 0.431 \\
$\gamma$ & 0.73476 & 0.03477 & 21.13 & 0.000 \\
R-Square & 0.6159 & & & \\
Adj. R-Square & 0.6124 & & & 0.000 \\
F(3, 324) & 173.19 & & & \\
\hline
\end{tabular}

Number of Observation $=328$

Table 11. Time-Varying OLS Regression Results: $R_{\text {mext }}=\alpha+\beta \Delta E P U_{t}+\theta \Delta T R D M E X_{t}+\gamma R_{s \& P 500 t}+\varepsilon_{t}$

\begin{tabular}{lcccc}
\hline & Coefficient & Std. Err. & $\boldsymbol{t}$ & Sig. \\
\hline Constant & 1.64866 & 0.40683 & 4.05 & 0.000 \\
$\beta$ & -0.01510 & 0.00964 & -0.61 & 0.546 \\
$\theta$ & 0.00004 & 0.00023 & 0.06 & 0.952 \\
$\gamma$ & 0.97524 & 0.03477 & 10.21 & 0.000 \\
R-Square & 0.2843 & & & \\
Adj. R-Square & 0.2769 & & & 0.000 \\
F(3, 289) & 38.27 & & & \\
\hline
\end{tabular}

Number of Observation $=293$

\section{Conclusion}

Motivated by a great deal of empirical evidence reported in the international economic and financial transmission and cross-border spillovers literature, this study investigates the effect of economic policy uncertainty in the United States on stock market performance in Canada and Mexico. Using monthly returns of the Canada S\&P/TSX-300 Total Return Index from 1985:2 to 2012:5 and Mexico SE Total Return Index from 1988:1 to 2012:5, this study shows that the increased changes in economic policy uncertainty in the US negatively affect stock market performance in Canada and Mexico. Although the changes in the U.S. trade balance do not influence the effect of the changes in economic policy uncertainty in the US on the stock market performance in Canada and Mexico, the returns on the S\&P 500 do influence this effect. The findings suggest that stock market performance in Canada and Mexico is linked to the economic policy conditions and stock performance in the US. The implication of this finding is that market participants in Canada and Mexico do pay 
attention to the economic policy conditions and stock performance in the US.

This study provides an important implication for equity investment and risk management. During the periods of high economic policy uncertainty in the US, investors can sell or short the stock market indices in Canada and Mexico. In contrast, during times with lower economic policy uncertainty, market participants can expect higher returns from investing in the stock markets in Canada and Mexico. For risk management implication, the findings suggest that it is difficult to diversify by investing in the stock markets in Canada and Mexico when investors are simultaneously investing in the U.S. stock market because not only do the increased changes in economic policy uncertainty in the US affect stock market performance in the US, these changes also affect stock market performance in Canada and Mexico as well.

\section{References}

Ammer, J., Vega, C., \& Wongswan, J. (2008). Do fundamentals explain the international impact of U.S. interest rates? Evidence at the firm level. Board of Governors of the Federal Reserve System International Finance Discussion Papers, Number 952, October.

Awad M. A., \& Barry, G. K. (1998). Dynamic linkages among real interest rates in international capital markets. Journal of International Money and Finance, 17, 881-907. http://dx.doi.org/10.1016/S0261-5606(98)00032-1

Baker, S. R., Bloom, N., \& Davis, S. (2012). Measuring economic policy uncertainty. Stanford mimeo.

Bansal, R., \& Yaron, A. (2002). Risk for the long run: A potential resolution of asset pricing puzzles. Journal of Finance, 59(1), 1481-1509. http://dx.doi.org/10.1111/j.1540-6261.2004.00670.x

Bansal, R., Khatchatrian, V., \& Yaron, A. (2005). Interpretable asset markets? European Economic Review, 49, 531-560. http://dx.doi.org/10.1016/j.euroecorev.2004.09.002

Bayoumi, T., \& Swiston, A. (2007). Foreign entanglements: Estimating the source and size of spillovers across industrial countries. IMF Working Paper WP/07/128, June.

Becker, K. G., Finnerty, J. E., \& Friedman, J. (1995). Economic news and equity market linkages between the U.S. and U.K. Journal of Banking and Finance, 19, 1191-1210. http://dx.doi.org/10.1016/0378-4266(94)00079-I

Bernanke, B. (1983). Irreversibility, uncertainty and cyclical investment. Quarterly Journal of Economics, 98 , 85-106. http://dx.doi.org/10.2307/1885568

Cochrane. (1991b). Production-based asset pricing and the link between stock returns and economic fluctuations. Journal of Finance, 46, 207-234. http://dx.doi.org/10.1111/j.1540-6261.1991.tb03750.x

Cooper, I., \& Richard Priestley, R. (2005). Stock return predictability in a production economy. Proceedings of the 2005 American Finance Association, Boston, MA.

Dzielinski, M. (2011). Measuring economic uncertainty and its impact on the stock market. Finance Research Letters, 9(3), 167-175. http://dx.doi.org/10.1016/j.frl.2011.10.003

Ehrmann, M., \& Fratzcher, M. (2006). Global financial transmission of monetary policy shocks. Oxford Bulletin of Economics and Statistics, 71(6), 739-759. http://dx.doi.org/10.1111/j.1468-0084.2009.00561.x

Ehrmann, M., \& Fratzscher, M. (2005). Equal size, equal role? Interest rate interdependence between the Euro area and the United States. The Economic Journal, 115, 928-948. http://dx.doi.org/10.1111/j.1468-0297.2005.01025.x

Ehrmann, M., Fratzscher, M., \& Rigobon, R. (2005). Stock, bonds, money markets and exchange rates: Measuring international financial transmission. Journal of Applied Econometrics, 26(6), 948-974. http://dx.doi.org/10.1002/jae.1173

Fernandez-Villaverde, J., Guerron-Quintana, P., Kuester, K., \& Rubio-Ramirez, J. (2012). Fiscal volatility shocks and economic activity. University of Pennsylvania mimeo.

Forbes, K. J., \& Chinn, M. D. (2004). A decomposition of global linkages in financial markets over time. Review of Economics and Statistics, 86(3), 705-722.

Gilchrist, S., Jae W. Sim, S. J., \& Zakrajsek, E. (2010). Uncertainty, financial friction and investment dynamics. Working paper, Boston University and Federal Research Board.

Goldberg, L., \& Leonard, D. (2003). What moves sovereign bond markets? The effects of economic news on U.S. and German yields. Federal Reserve Bank of New York, Current Issues in Economics and Finance, 9 
(9), 1-7.

Hausman, J., \& Wongswan, J. (2011). Global asset prices and FOMC announcements. Journal of International Money and Finance, 30(3), 547-571. http://dx.doi.org/10.1016/j.jimonfin.2011.01.008

Julio, B., \& Yook, Y. (2012). Political uncertainty and corporate investment cycles. Journal of Finance, 67(1), 45-84. http://dx.doi.org/10.1111/j.1540-6261.2011.01707.x

Kim, S. (2001). International transmission of U.S. monetary policy shocks: Evidence from VAR's. Journal of Monetary Economics, 48, 339-372. http://dx.doi.org/10.1016/S0304-3932(01)00080-0

King, M. A., \& Wadhwani, S. (1990). Transmission of volatility between stock markets. Review of Financial Studies, 3, 5-33. http://dx.doi.org/10.1093/rfs/3.1.5

Lamont, O. (2000). Investment plans and stock returns. Journal of Finance, 55, 2719-2745. http://dx.doi.org/10.1111/0022-1082.00304

Lettau, M., \& Ludvigson, S. (2001a). Consumption, aggregate wealth, and expected stock returns. Journal of Finance, 56, 815-49. http://dx.doi.org/10.1111/0022-1082.00347

Lin, W., Engle, R. F., \& Ito, T. (1994). Do bulls and bears move across borders? International transmission of stock returns and volatility. Review of Financial Studies, 7, 507-538.

Menzly, L., Santos, T., \& Veronesi, P. (2004). Understanding predictability. Journal of Political Economy, 112, 1-47. http://dx.doi.org/10.1.1.202.5546

Pastor, L., \& Veronesi, P. (2012). Uncertainty about government policy and stock prices. Journal of Finance, 67(4), 1219-1264. http://dx.doi.org/10.1111/j.1540-6261.2012.01746.x

Piazzesi, M. (2005). Bond yields and the Federal Reserve. Journal of Political Economy, 113, 311-344.

Rodrik, D. (1991). Policy uncertainty and private investment. Journal of Development Economics, 36, 229-242. http://dx.doi.org/10.1016/0304-3878(91)90034-S

Sum, V. (2012). Economic policy uncertainty and stock market performance: Evidence from the European Union, Croatia, Norway, Russia, Switzerland, Turkey and Ukraine. Journal of Money, Investment and Banking. (Forthcoming)

Sum, V. (2012). Economic policy uncertainty and stock market returns. International Review of Applied Financial Issues and Economics. Forthcoming

Wongswan, J. (2003). Transmission of information across international equity markets. Review of Financial Studies, 19(4), 1157-1189. http://dx.doi.org/10.1093/rfs/hhj033 